\title{
A Lymphoblastoid Cell Line with High Phagocytic Activity Established from Peripheral Blood of a Patient with Chronic Myelocytic Leukemia in Blast Crisis
}

\author{
Kazuhiro Mitani ${ }^{1}$, Fuminori Hyodoh ${ }^{1}$, Yoshihito Yawata $^{2}$, and Tetsuo \\ Kimoto $^{1}$ \\ Department of Pathology ${ }^{1}$ and Medicine,$^{2}$ Kawasaki Medical School, Kurashiki \\ 701-01, Japan
}

\begin{abstract}
A human hematopoietic cell line (K-23-M) was established from a patient with chronic myelocytic leukemia in blast crisis. Morphologically, the cultured cells were lymphoblastoid cells that produced IgA and were Epstein-Barr viral nuclear antigen positive. But they showed high phagocytic activity to glutaraldehyde-treated sheep red cells and had properties of a monocyte or macrophage that included surface Fc receptors, $a$-naphthyl butyrate esterase positivity blocked by $\mathrm{NaF}$, migration in soft agar and the ability to attach to a glass surface. Lysozyme secretion was absent, and chromosomes were diploid and $\mathrm{Ph}^{1}$ negative. This cell line is unique in that it has strong phagocytic activity. Its existence shows that lymphoblastoid cell line may be a more important cell line for the study of human hematopoietic cells than previously has been believed.
\end{abstract}

Almost all human hematopoietic cell lines are "lymphoblastoid cell lines (LCLs)". Because LCLs have EBNA, and produce immunoglobulins, they have been believed to be B-lymphocytic cell lines (22). Kimoto et al. (11), however, reported that Mono-1 was morphologically an LCL but had the properties of a monocytic cell. Furthermore, Mono-1-207, a subline of Mono-1, showed lobulation like that of neutrophils in arginine dificient medium (12).

After Kimoto's report, differentiation to granulocytes or macrophages in arginine deficient conditions was demonstrated by Okabe et al. (23) using M-1 (10), and by Honma et al. (7) using HL-60 (2). Recently, K-562 (15) has been reported to differentiate to monocytic, granulocytic and erythrocytic cells in media gradually depleted of essential nutrients (16). As a result, the possibility has been strengthened that Mono-1-207 is morphologically an LCL, but with the characteristics of the myeloid precursor cell line.

Because we consider that B-lymphocytic characteristics only one aspect of an LCL, we conducted a series of experiments to determine whether there is a cell line among the LCLs with remarkable monocytic, myelocytic, or erythrocytic properties. We

\footnotetext{
Abbreviations used: ANBE, $a$-naphthyl butyrate esterase; EBNA, Epstein-Barr viral nuclear antigen; FCS, fetal calf serum; GRC, glutaraldehyde-treated sheep red cells; LCL, lymphoblastoid cell line; $\mathrm{Ph}^{1}$, Philadelphia chromosome; TdT, terminal deoxyribonucleotidyl transferase; TEM, transmission electron microscope.
} 
here report an interesting LCL (K-23-M) with monocytic properties, particularly strong phagocytic activity.

\section{MATERIALS AND METHODS}

Establishment of $K-23-M$. Peripheral blood was obtained on Oct. 10, 1979 from a patient (55-year-old female) with chronic myelocytic leukemia in blast crisis that morphologically changed to acute promyelocytic leukemia. Mononuclear cells were collected by FicollHypaque gradient centrifugation then suspended in RPMI 1640 medium with $23 \%$ heatinactivated FCS (Flow Laboratories, U.S.A.). Four-milliliter portions of this suspension $\left(10^{6}\right.$ cells $\left./ \mathrm{ml}\right)$ were placed in $60-\mathrm{mm}$ petri dishes and incubated at $37^{\circ} \mathrm{C}$ in a $5 \% \mathrm{CO}_{2}$-incubator.

After the 63rd day of culture, a lymphoblastoid cell line, designated K-23-M, was established. After 3 months of culture, RPMI 1640 with $10 \%$ FCS was used to maintain the line, and the medium was changed once every 3-5 days.

Cytological and cytochemical observations. Cover slip smears from the cultured cells were stained with Wright-Giemsa for light microscopy. For the TEM examination, the method described previously (18) was used. For the cytochemical study, smears were stained with peroxidase (6), ANBE and naphthol AS-D chloroacetate esterase (14), and acid phosphatase (30). TEM observations also were made on samples stained with peroxidase (29).

$F c$ and $C_{3}$ receptors. Agglutination and rosette-forming tests wereperformed by a procedure similar to that used in the identification of T- and B-cells and monocytes (32).

Detection of cytoplasmic immunoglobulins. FITC-conjugated goat antisera against human IgG, IgM and IgA were purchased from E-Y Laboratories, Inc., U.S.A. Direct immunofluorescence techniques were used.

Detection of EBNA. A mixture of serum proved anti-EBNA positive by the Special Reference Laboratory, Japan, and fresh serum was used as the first solution. FITC-conjugated goat anti-human $\mathrm{C}_{3}$ from E-Y Laboratories was the second solution. After treatment with the first solution, the direct immunofluorescence technique was used. P3HR-1, Raji, and EB-3 cells were the positive controls and rat liver cells the negative control.

Assay of lysozyme activity. The lysoplate method (24) was used in which culture supernatants and cell lysates were the samples and lysozyme of egg white (Sigma Chemical Co., St Louis, Mo.) the control.

Chromosomal analysis. Cells were collected after treatment with colchicine for $2 \mathrm{~h}$. The preparations were treated with $0.075 \mathrm{M} \mathrm{KCl}$ for $8 \mathrm{~min}$, then fixed with ethanol/acetic acid $(3: 1)$, flame-dried and stained with Giemsa. One hundred metaphase cells were studied.

TdT assay and monoclonal antibody tests. The indirect immunofluorescence technique was employed. Anti-TdT and anti-human monocyte sera were purchased from Bethesda Research Laboratories, Inc., U.S.A. and anti-human B-lymphocyte serum from Sera-Lab., Co., Ltd., England.

Phagocytic activity. Sheep red cells treated with $2.5 \%$ glutaraldehyde for one day (GRC) were washed with a sufficient quantity of PBS then stored at $4^{\circ} \mathrm{C}$ as a suspension in PBS (27). Suspensions of $2 \times 10^{7} \mathrm{GRC}$ and $5-20 \times 10^{5}$ line cells were made in centrifuge tubes containing $1 \mathrm{ml}$ of RPMI 1640 with $40 \%$ FCS. These were centrifuged for $3 \mathrm{~min}$ at $150 \times \mathrm{g}$ then kept in a $5 \% \mathrm{CO}_{2}$-incubator $4 \mathrm{~h}$, after which 2-3 drops of trypan blue were added for the count in an improved Neubauer hemocytometer with bright-lines (Kayagaki Irikakogyo Co., Ltd., Japan). Four hundred viable cells were examined with the differential counter and divided into 4 groups: those phagocytizing no cells, those phagocytizing one cell, those 
phagocytizing 2-3 cells and those phagocytizing more than 4 cells. Phagocytic activity was measured after 6 months of culture.

\section{RESULTS}

Cytological and cytochemical observations. K-23-M cells in culture photographed under phase contrast microscopy are shown in Fig. 1. Some cells formed clumps, some adhered to the glass surface and some were suspended as individual cells. A single cell was approximately 5-25 $\mu \mathrm{m}$. Most cells had the "hand-mirror" shape with slender pseudopodia at one end (the uropod). Sometimes they showed a strong tendency to clump, the uropods pointing away from the center. When they adhered to the glass surface, they tended to assume a fibroblast shape or the dendritic type of macrophage shape. These findings are consistent with the definition of a "lymphoblastoid cell line" given by Nilsson and Ponten (22). In soft agar some cells showed locomotive mobility. After Wright-Giemsa staining, the pseudopodia cells resembled none of the hematopoietic cells seen in vivo. But, there were some cells similar to plasmocytes or macrophages.

TEM examination showed scattered globules and spherical mitochondria as described by Moore et al. (19). No herpes virus-like particles were found.

Cytochemical examination disclosed that the $a$-naphthyl butyrate esterase (ANBE) and acid phosphatase stainings were positive. The peroxidase and naphthol AS-D chloroacetate esterase stainings were negative.

The stainability of ANBE varied; sometimes it was diffusely positive, sometimes it disappeared completely. Usually, however, cells were stained in a weakly positive dot (33). For cells that were positive, treatment with stain containing $0.04 \mathrm{M} \mathrm{NaF}$ after treatment with $0.04 \mathrm{M} \mathrm{NaF}$ solution for 1 min produced negative stainability. When the stainability was negative without $\mathrm{NaF}$, cells that had been washed 3 times

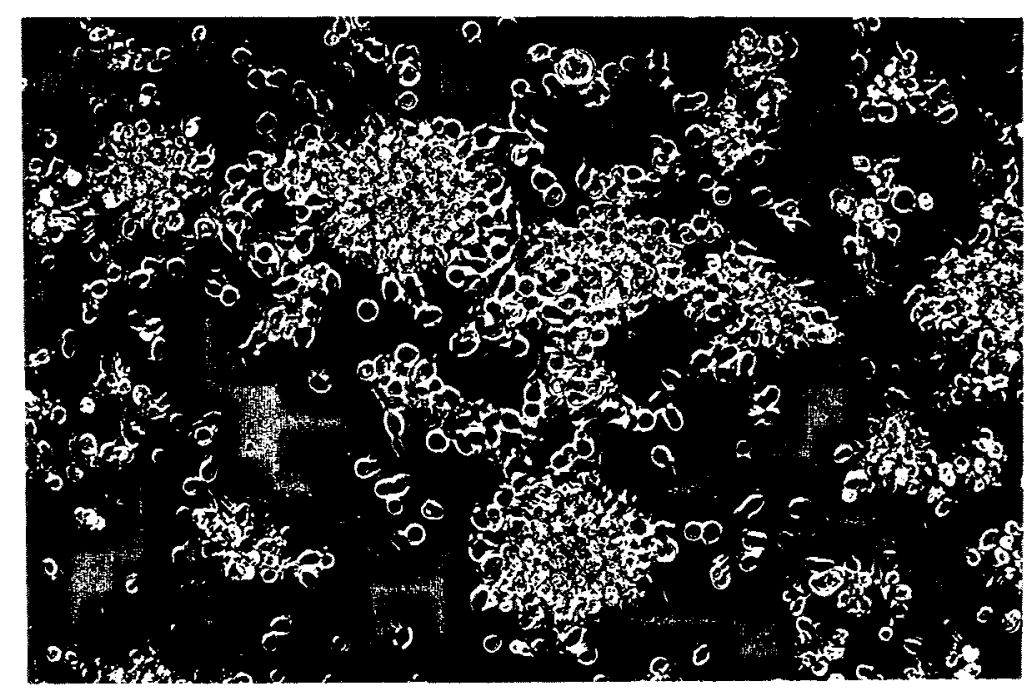

Fig. 1. K-23-M cells in culture seen through an inverted phase contrast microscope. Cells have characteristics of an LCL. $\times 200$. 


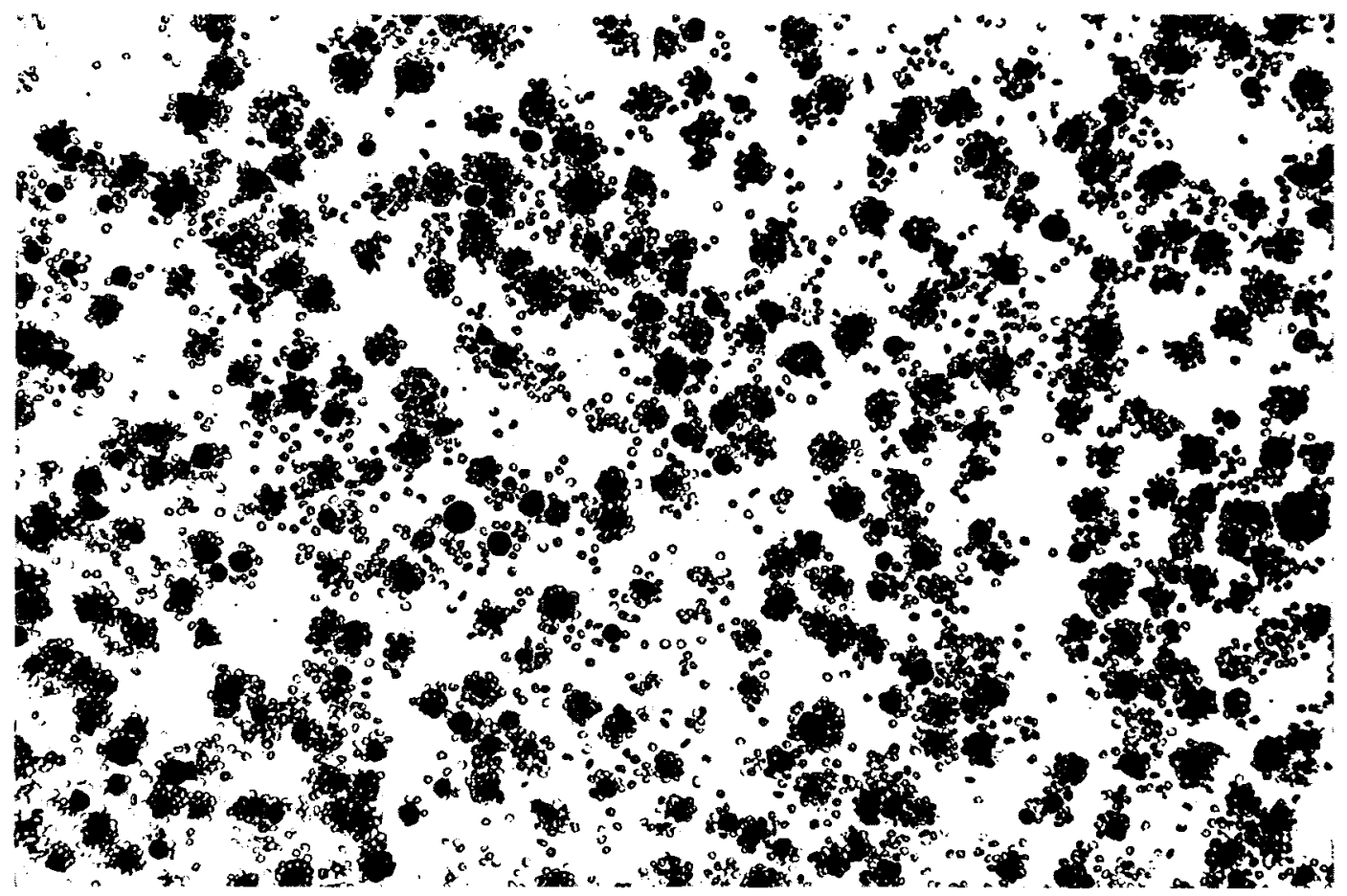

Fig. 2. Fc receptors of K-23-M cells cultured for 9 months. Phagocytes also are present. $\times 250$.

with PBS turned positive in some instances.

$F c$ and $C_{3}$ receptors. The presence of $F c$ receptors varied greatly, from only $2 \%$ of the cells at 8 months of culture to $85-97 \%$ at 9 months of culture and $24-38 \%$ at 11 months of culture. $\mathrm{Fc}$ receptors (EA $\mathrm{EAs}_{7 \mathrm{~s}}$ rosette-forming test) at 9 months of culture are shown in Fig. 2. $\mathrm{C}_{3}$ receptors always present in more than $70 \%$ of the cultured cells. Spontaneous rosette formation with sheep red cells took place in less than $5 \%$

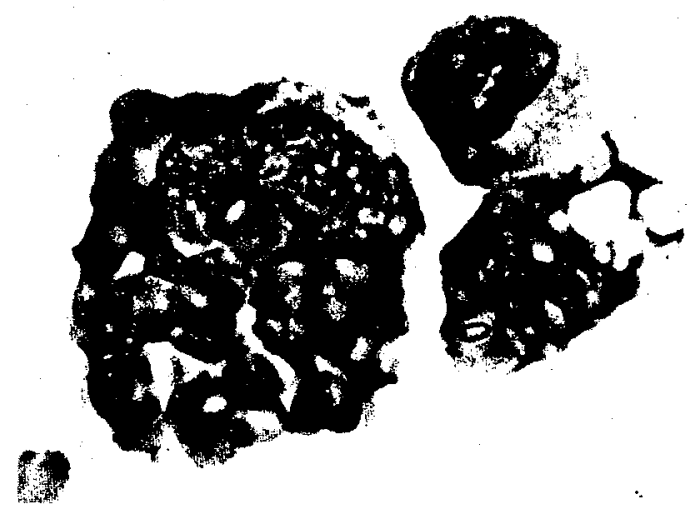

Fig. 3. GRC phagocytosis of K-23-M cells. A macrophage-like phagocyte is present. $\times 1,600$. 
of the cells.

Cytoplasmic immunoglobulins. Some cells were always IgA positive. IgG sometimes was weakly positive and sometimes negative. IgM was always negative.

$E B N A$. In the early period of culture, $\mathrm{K}-23-\mathrm{M}$ cells were EBNA negative; but, after 8-12 months of culture, they became EBNA positive.

Lysozyme activity. Up to day 76 , the culture supernatants had lysozyme activity. Thereafter, both the cell lysates and supernatants became negative for this activity.

Chromosome analysis. The patient's peripheral blood before the onset of blast crisis was $\mathrm{Ph}^{1}$ positive, whereas afterwards those few cells that underwent mitosis did not show $\mathrm{Ph}^{1}$. K-23-M cells were $\mathrm{Ph}^{1}$ negative. In every group, the chromosome

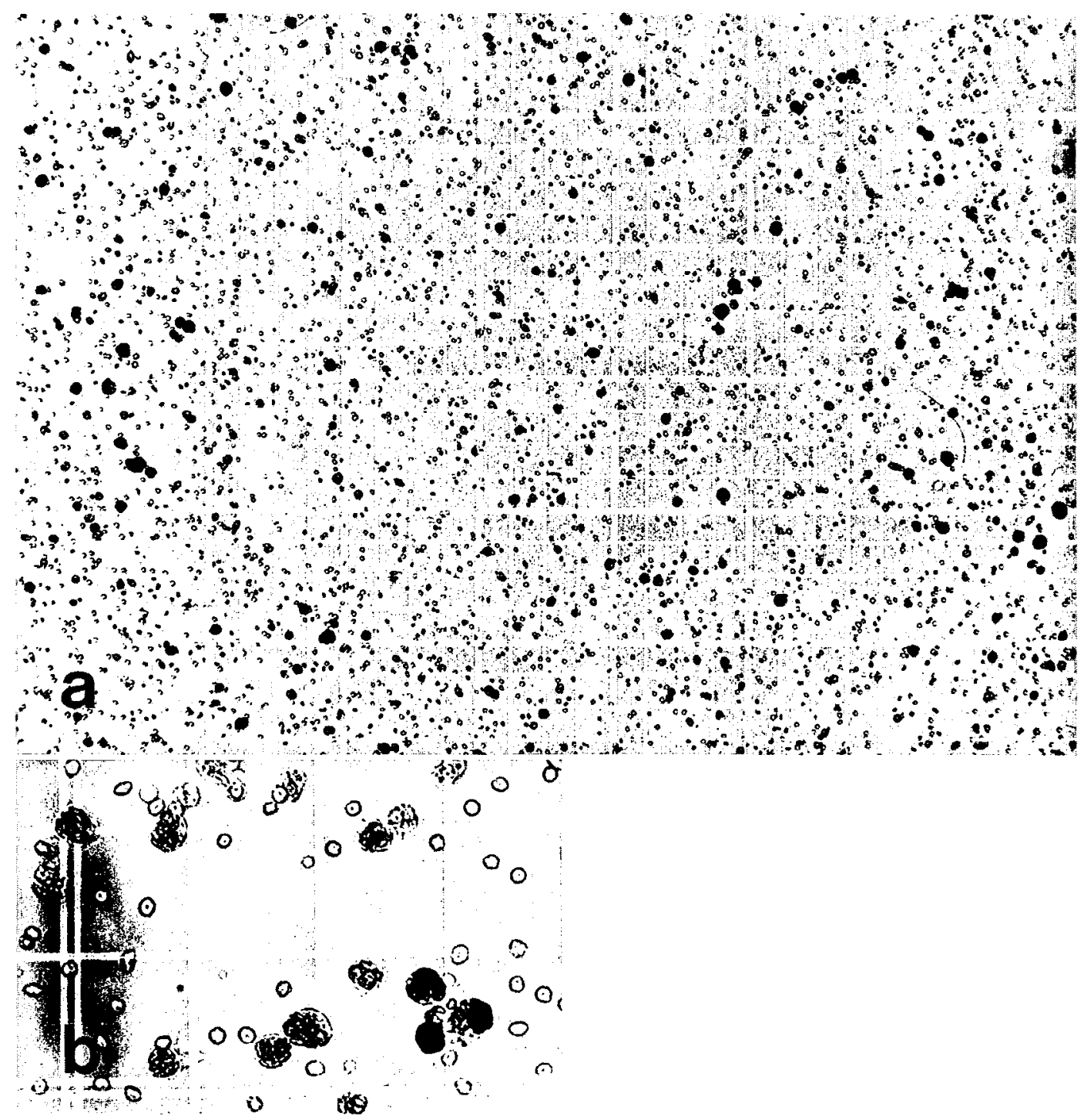

Fig. 4. Phagocytes on the hemocytometer. (a) $\times 100$, (b) $\times 400$. 


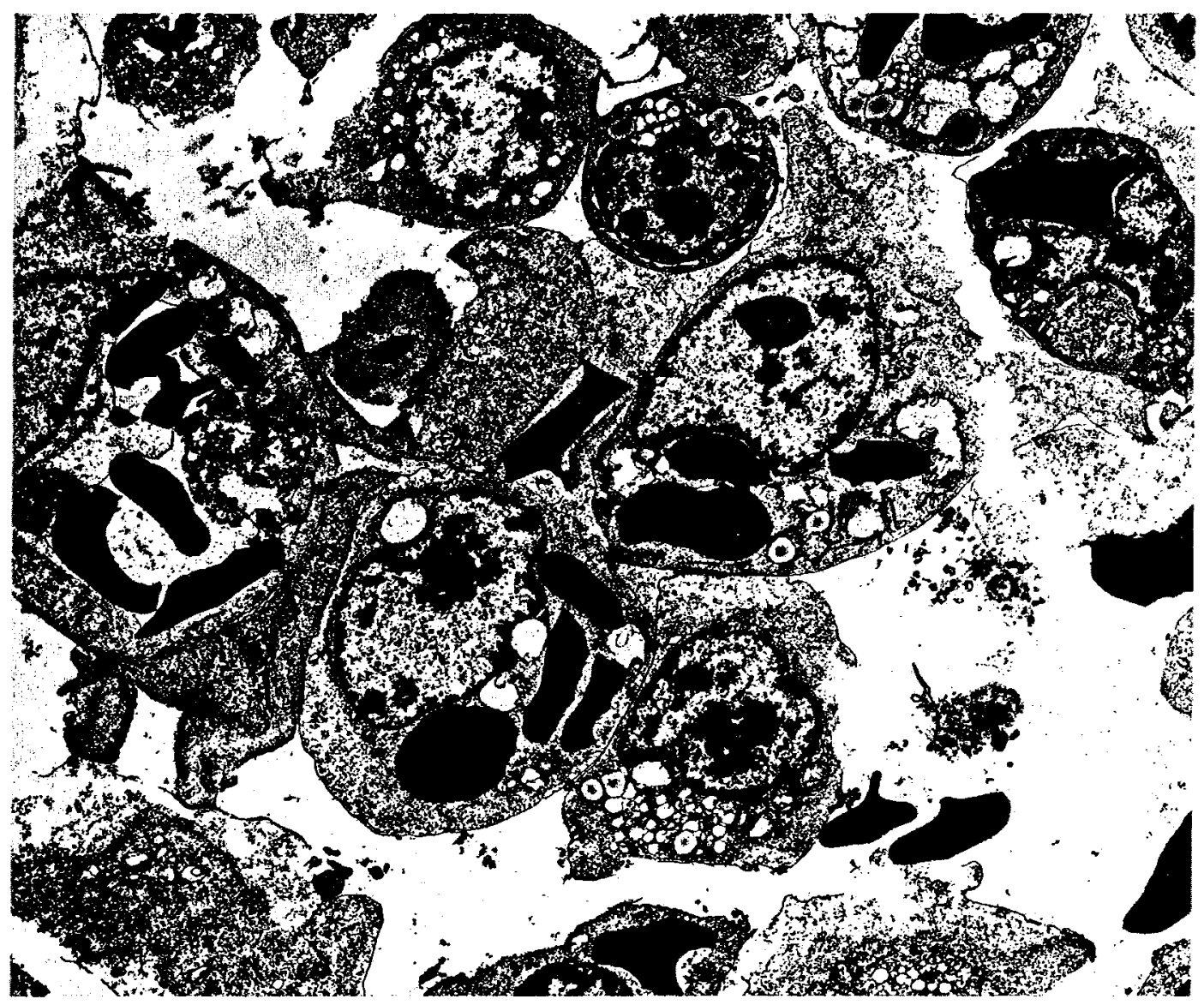

Fig. 5. TEM observations confirm the GRC phagocytosis of K-23-M cells. $\times 3,500$.

number was 46: diploid.

$T d T$ assay and monoclonal antibody tests. Anti-TdT, anti-monocyte and anti-B lymphocyte sera were always negative to immunofluorescence against $\mathrm{K}-23-\mathrm{M}$.

Phagocytic activity. K-23-M cells showed strong phagocytic activity. GRC phagocytosis by K-23-M cells is shown in Figs. 3, 4 and 5. In Figs. 3 and 4, many lymphoblastoid cells are undergoing marked phagocytosis similar to that seen only in monocytes and macrophages.

The percentage of phagocytosis in the line cells (\%phagocytosis) rose in direct proportion to the concentration of FCS added at the start of the incubation for the examination of phagocytosis (Table 1). This ascending curve reached a peak at about $40-60 \%$ FCS then maintained a plateau up to $100 \%$ FCS.

Results of experiments to determine the necessity of centrifugation and the optimal period of incubation are shown in Table 2. For all subsequent experiments samples were centrifuged at $150 \times \mathrm{g}$ for $3 \mathrm{~min}$ and the incubation time was $4 \mathrm{~h}$.

The $\%$ phagocytosis also varied with the medium used before the examination of phagocytosis. Cells cultured in medium with a low FCS content showed a high 
TABLE 1. ACtivation OF PHAGocytosis of K-23-M Cells With FCS ${ }^{a}$

\begin{tabular}{cccccc}
\hline & \multicolumn{2}{c}{ K-23-M cells phagocytizing sheep red cells $(\%)$} & & \% phagocytosis \\
\cline { 2 - 5 } & 0 & 1 & $2-3$ & $\geqq 4^{b}$ & \\
\hline 0 & 75 & 8 & 8 & 8 & 25 \\
10 & 61 & 16 & 12 & 11 & 39 \\
20 & 55 & 20 & 11 & 14 & 45 \\
40 & 37 & 22 & 23 & 19 & 63
\end{tabular}

a Phagocytic activity was observed after $4 \mathrm{~h}$ of incubation in medium that contained 0 to $40 \% \mathrm{FCS}$. Phagocytized sheep red cells had been treated with $2.5 \%$ glutaraldehyde.

$b$ Number of red cells phagocytized per cell.

TABLE 2. TIME COURSE OF ACTIVATION OF PHAGOCYTIC ACTIVITY OF K-23-M CELLS WITH $40 \%$ FCS

\begin{tabular}{|c|c|c|c|c|c|c|}
\hline \multirow{2}{*}{ Hour $^{c}$} & \multicolumn{5}{|c|}{ K-23-M cells phagocytizing sheep red cells $(\%)$} & \multirow{2}{*}{$\%$ phagocytosis } \\
\hline & & 0 & 1 & $2-3$ & $\geqq 4$ & \\
\hline \multirow[t]{2}{*}{1} & $\mathrm{n}^{a}$ & 95 & 4 & 1 & 0 & 5 \\
\hline & c & 66 & 15 & 10 & 10 & 34 \\
\hline \multirow[t]{2}{*}{2} & $\mathrm{n}$ & 85 & 9 & 5 & 1 & 15 \\
\hline & c & 64 & 14 & 12 & 11 & 36 \\
\hline \multirow[t]{2}{*}{3} & $\mathrm{n}$ & 71 & 15 & 7 & 7 & 29 \\
\hline & c & 55 & 15 & 11 & 20 & 46 \\
\hline \multirow[t]{2}{*}{4} & $\mathrm{n}$ & 68 & 12 & 10 & 10 & 32 \\
\hline & c & 54 & 15 & 13 & 18 & 47 \\
\hline \multirow[t]{2}{*}{5} & $\mathrm{n}$ & 64 & 12 & 9 & 16 & 36 \\
\hline & c & 45 & 16 & 17 & 23 & 55 \\
\hline
\end{tabular}

${ }^{a} \mathrm{n}=$ no centrifugation. $\mathrm{c}=$ centrifugation $^{b}$.

$b$ Before incubation K-23-M cells mixed with glutaraldehyde-treated sheep red cells in RPMI 1640 medium containing $40 \%$ FCS were centrifuged at $150 \times \mathrm{g}$ for $3 \mathrm{~min}$.

c Incubation period.

TABLE 3. RELATION BETWEEN \% PHAGOCYTOSIS AND CONCENTRATION OF FCS IN THE CULTURE MEDIUM ${ }^{a}$

\begin{tabular}{|c|c|c|c|c|c|c|}
\hline \multirow{2}{*}{$\operatorname{FCS}(\%)$} & \multicolumn{4}{|c|}{ K-23-M cells phagocytizing sheep red cells ( $\%)$} & \multirow{2}{*}{$\%$ phagocytosis } & \multirow{2}{*}{$\left(\frac{\text { cell count }^{b}}{\times 10^{5} / \mathrm{ml}}\right)$} \\
\hline & 0 & 1 & $2-3$ & $\geqq 4$ & & \\
\hline 5 & 68 & 9 & 7 & 17 & 32 & $(2.5)$ \\
\hline 10 & 75 & 13 & 4 & 9 & 25 & $(7.1)$ \\
\hline 20 & 80 & 8 & 4 & 7 & 20 & $(14.1)$ \\
\hline 40 & 79 & 4 & 4 & 13 & 21 & $(16.7)$ \\
\hline
\end{tabular}

a After 4 days of incubation in medium containing 5 to $40 \%$ FCS, phagocytic activity was checked after $4 \mathrm{~h}$ of incubation in medium plus $40 \% \mathrm{FCS}$.

${ }_{b}$ Cell count on the 5 th day of incubation. The cell count on the 1 st day was $2 \times 10^{5} / \mathrm{ml}$. 


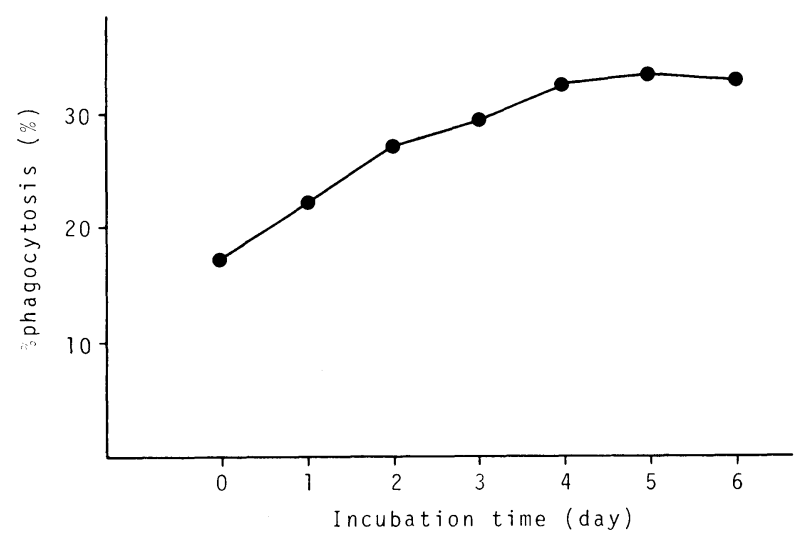

Fig. 6. Changes of $\%$ phagocytosis in the medium containing $5 \%$ FCS. This experiment was done on the 5 th day of incubation in medium containing $40 \%$ FCS. After being washed, K-23-M cells were incubated in medium containing $5 \%$ FCS. Phagocytic activity was counted daily for 6 days.

$\%$ phagocytosis (Table 3). As shown in Fig. 6, the \%phagocytosis for K-23-M cells rose continuously in medium with $5 \%$ FCS.

The \%phagocytosis of the K-23-M cells varied widely (Tables 1, 2, 3 and Fig. 6). It was impossible to obtain stable data for the phagocytic activity of this cell line. The $\%$ phagocytosis ranged from a high of $69 \%$ to a low of $5 \%$, but there were no significant differences in mean \%phagocytosis (about 27\%) among the 23 cloned sublines of K-23-M obtained by the soft agar method.

In addition, cytoplasmic IgA was checked with smears of phagocytizing K-23-M cells. Most phagocytizing cells did not produce IgA, and most IgA-positive cells did not phagocytize GRC, but a number of cells showed both phagocytosis and IgA production (Fig. 7). This phenomenon was present in each cloned subline.

\section{DISCUSSION}

The term "LCL" was defined by Nilsson and Pontén (22) as a cell line that produces immunoglobulin, is EBNA positive and diploid, and shows characteristic growth as free-floating clumps of pear-shaped cells extending their uropods in a centrifugal direction. Therefore, K-23-M is an LCL.

An LCL is considered a B-cell line, but monocytic properties of LCLs frequently have been reported; phagocytic activity $(5,19,21)$, a high density of Fc receptors $(8,11)$, positive stainability of ANBE that is blocked by NaF $(13,18)$, migration in soft agar and attachment to glass surfaces with a change in form to the dendritic type of macrophage shape (22). These properties are observed only in monocytic cells under normal conditions, but because LCLs have been considered B-cell lines, these monocytic properties are believed to be acquired characteristics.

Reports of phagocytosis of lymphocytic cells have been made that include normal lymphocytes (9), acute lymphocytic leukemia cells (4) and myeloma cells $(3,17)$. There also has been a report that acute lymphoblastic leukemia cells autonomously produce parathyroid hormone (28). Therefore, it is not unusual to find lymphocytic 


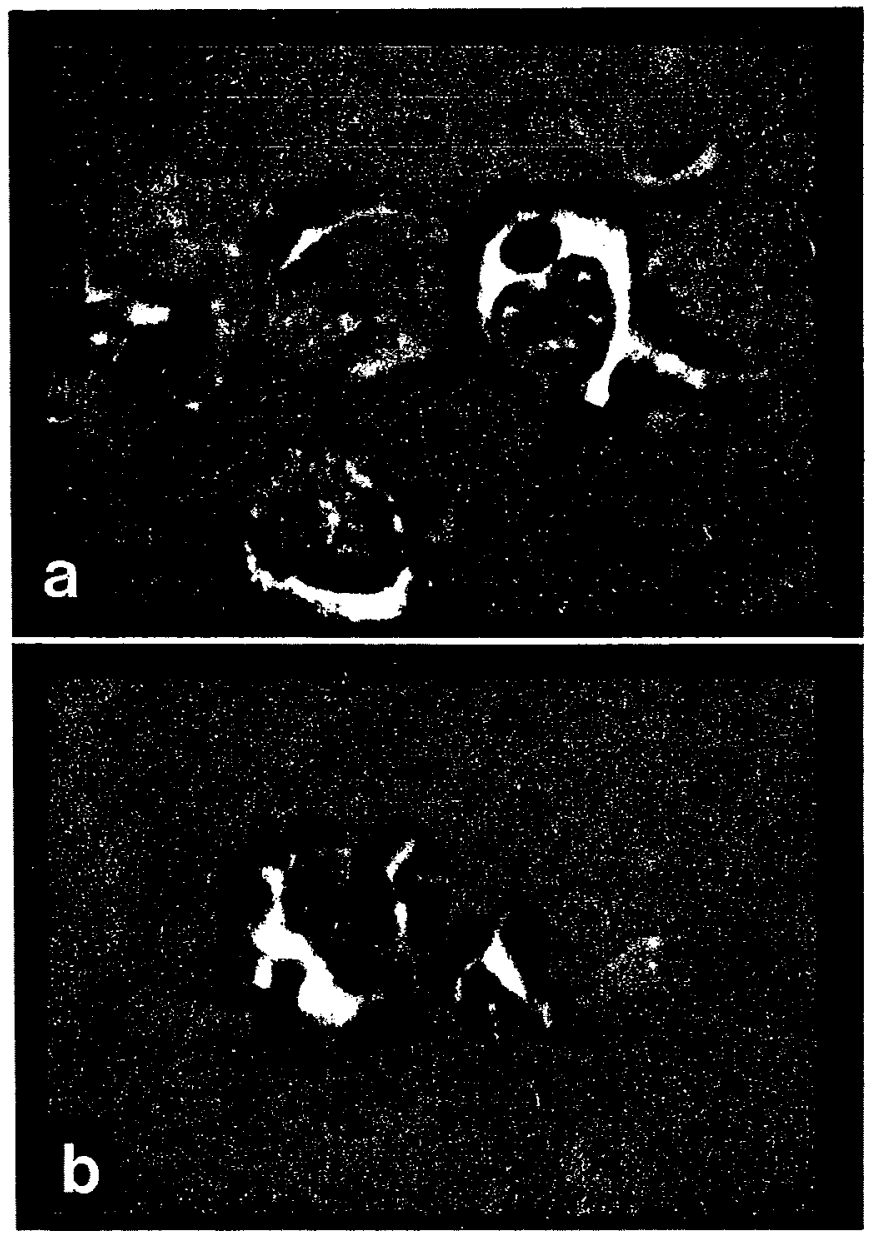

Fig. 7. GRC phagocytosis of IgA-producing K-23-M cells. $\times 1,600$.

cells that have acquired monocytic properties after long term culture.

As reported previously, Mono-1-207 is an LCL, but study of its differentiation has enhanced the possibility of its being a myeloid precursor cell line. There has been no report of immunoglobulin-producing cells differentiating to mature granulocytes so it is extremely difficult to explain the potency of Mono-1-207 according to the previous theory of LCLs.

We observed remarkable monocytic properties in an LCL. There has been no previous report of an LCL with such strong phagocytic activity and high density of Fc receptors. We found that some phagocytizing K-23-M cells are difficult to distinguish from phagocytizing macrophages (Fig. 3). Moreover, the phagocytized particles used in our experiment were GRC. A GRC can not attach to lymphocytes because of its negative surface charge $(20,26)$. Therefore, if only this one characteristic is considered, K-23-M might be considered a monocytic cell line. This would be incorrect because $\mathrm{K}-23-\mathrm{M}$ cells can produce $\mathrm{IgA}$.

To explain this phenomenon found in Mono-1-207 and K-23-M cells, we have 
TABLE 4. TEST FOR ACTIVATION OF PHAGOCYTOSIS

\begin{tabular}{|c|c|c|c|c|c|}
\hline \multirow{2}{*}{ Activator } & \multicolumn{4}{|c|}{ K-23-M cells phagocytizing sheep red cells $(\%)$} & \multirow{2}{*}{$\%$ phagocytosis } \\
\hline & 0 & 1 & $2-3$ & $\geqq 4$ & \\
\hline $40 \% \mathrm{CS}$ & 99 & 1 & 0 & 1 & 1 \\
\hline Serum free & 83 & 7 & 5 & 6 & 17 \\
\hline $40 \% \mathrm{FCS}$ & 65 & 10 & 10 & 15 & 35 \\
\hline
\end{tabular}

This experiment was done on the 5 th day of incubation with serum free medium containing $5 \mu \mathrm{g}$ Insulin and $5 \mu \mathrm{g}$ Transferrin $/ \mathrm{ml}$.

After being washed, K-23-M cells were incubated in the medium combinations for $4 \mathrm{~h}$.

made a new hypothesis: An LCL is a differentiating cell line. The stem cell is pluripotent and the terminal, differentiated cells are plasmocytic and monocytic cells. Because its differentiated cells are mainly plasmocytic, the LCL has been believed to be a B-cell line.

The proportion of phagocytic cells increased in medium with $5 \%$ FCS (Fig. 6). This phenomenon is explainable if $\mathrm{K}-23-\mathrm{M}$ is a differentiating cell line, as $\mathrm{K}-23-\mathrm{M}$ cells differentiate in both $5 \%$ and $40 \%$ FCS media. Because they proliferate slowly in low FCS medium, the percentage of differentiated cells (phagocytes) is relatively high in medium with $5 \%$ FCS. Therefore, Fig. 6 shows how the proportion of nonphagocytes and phagocytes changes from the value in medium containing $40 \%$ FCS to that in medium containing $5 \%$ FCS.

If an LCL is a differentiating cell line, it explains not only the granulocytic differentiation of Mono-1-207 and the phagocytic activity of K-23-M but the other monocytic and lymphocytic properties of an LCL as well. As to immunoglobulin production, very wide variations in the number of immunoglobulin-producing cells in lymphoblastoid cells $(2.5-25 \%)$ were found by Takahashi et al. (31) in cloned sublines of an LCL. This phenomenon also is accounted for if LCLs are considered differentiating cell lines.

As to the percent of phagocytosis increasing in direct proportion to the concentration of FCS, the same phenomenon has been reported for mouse macrophages (27). This leads us to the conclusion that FCS has phagocyte activating activity. This activity was found for FCS, but not for calf serum (Table 4).

Even if an LCL is not a differentiating cell line and its monocytic properties are acquired characteristics, there is the fact that B-lymphocytes easily acquire monocytic properties. Another important fact is that almost no LCLs produce IgM, the most common immunoglobulin produced by B-lymphocytes.

Because of its remarkable monocytic properties, K-23-M may be useful for proving our hypothesis or for accounting for contradictory facts stated above.

Acknowledgements. We thank Associate Professor M. Namba and Assistant Professor A. Ueki of the Department of Pathology, Kawasaki Medical School, for their aid with the chromosomal analysis and the immunological technique. This work was supported by grants from the Ministry of Education, Science and Culture of Japan, and the Research Project-Grant of the Kawasaki Medical School. 


\section{REFERENCES}

1. Breitman, T.R., S.J. Collins and B.R. Keene. Terminal differentiation of human promyelocytic leukemia cells in primary culture in response to retinoic acid. Blood 57, 1000-1004, 1981

2. Collins, S.J., R.C. Gallo and R.E. Gallagher. Continuous growth and differentiation of human myeloid leukemia cells in suspension culture. Nature 270, 347-349, 1977

3. Fitchen, J.H. and S. Lee. Phagocytic myeloma cells. Am. J. Clin. Pathol. 71, 722-723, 1979

4. Foadi, M.D., A.M. Slater and G.D. Pegrum. Erythrophagocytosis by acute lymphoblastic leukemia cells. Scand. J. Haematol. 20, 85-88, 1978

5. Glade, P.R., J.A. Kasel, H.L. Moses, J. Whang-Peng, P.F. Hoffman, J.K. Kammermeyer and L.M. Chessin. Infectious mononucleosis: Continuous suspension culture of peripheral blood leukocytes. Nature 217, 564-565, 1968

6. Goud, T.J.L.M., C. Schotte and R. VAN FURTH. Identification and characterization of the monoblast in mononuclear phagocyte colonies grown in vitro. J. Exp. Med. 142, 1180-1197, 1975

7. Honma, Y., Y. Fujita, J. OKabe-Kado, T. Kasukabe and M. Hozumi. Induction of differentiation of human promyelocytic leukemia cells (HL-60) by arginase. Cancer Letters 10, 287292, 1980

8. Huber, C.H., C. Sundström, K. Nilsson and H. Wigzell. Surface receptors on human haematopoietic cell lines. Clin. Exp. Immunol. 25, 367-376, 1976

9. Hughes, N.S. Erythrocyte phagocytosis by human lymphocytes. Nature 212, 1575-1576, 1966

10. Ichikawa, Y. Differentiation of a cell line of myeloid leukemia. J. Cell Physiol. 74, 223-234, 1969

11. Kimoto, T., M. Namba, A. Ueki and F. Hyodoh. Characteristics of hematopoietic cell line established from human myelomonocytic leukemia. Virchows Arch. [Pathol. Anat.] 371, 15-26, 1976

12. Кімото, T., F. Нуодон, K. Nishitani, M. Namba, A. Ueki and Y. Nishioka. Differentiation to myeloid cells of lymphoblastoid cells established from myelomonocytic leukemia. Virchows Arch. [Pathol. Anat.] 379, 269-284, 1978

13. Кімото, T. and F. Нуорон. Long-term cultivation of acute myelomonocytic leukemia cells: partially differentiation to monocyte-macrophage-like cell. Recent Advances in RES Research 19, 1975-1982, 1979

14. Li, C.Y., K.W. LAM and L.T. YAM. Esterase in human leukocytes. J. Histochem. Cytochem. 21, 1-12, 1973

15. Lozzıo, C.B. and B.B. Lozzıo. Human chronic myelogenous leukemia cell-line with positive Philadelphia chromosome. Blood 45, 321-334, 1975

16. Lozzio, B.B., C.B. Lozzio, E.G. Bamberger and A.S. Feliu. A multipotential leukemia cell line (K-562) of human origin. Proc. Soc. Exp. Biol. Med. 166, 546-550, 1981

17. Ludwig, H. and M. Pavelka. Phagocytic plasma cells in a patient with multiple myeloma. Blood 56, 173-176, 1980

18. Mitani, K. Monocytic properties of four lymphoblastoid cell lines established from three patients with non-lymphocytic leukemia. Kawasaki Med. J. 7, 81-96, 1981

19. Moore, G.E., H. Kitamura and S. Toshima. Morphology of cultured hematopoietic cells. Cancer 22, 245-267, 1968

20. NAITO, M. and S. SENO. Importance of antigen-lymphocyte interaction in establishment of cellular immunity. Cell Biology International Reports 5, 675-681, 1981

21. Nilsson, K. Characteristics of established myeloma and lymphoblastoid cell lines derived from an E myeloma patient: a comparative study. Int. J. Cancer 7, 380-396, 1971

22. Nilsson, K. and J. Pontén. Classification and biological nature of established human hematopoietic cell lines. Int. J. Cancer 15, 321-341, 1975

23. OKabe, J., M. Hayashi, Y. Honma and M. Hozumi. Induction of differentiation of cultured mouse myeloid leukemic cells by arginase. Biochem. Biophys. Res. Commun. 89, 879-844, 1979

24. Osserman, E.F. and D.P. LAwlor. Serum and urinary lysozyme (muramidase) in monocytic and myelomonocytic leukemia. J. Fxp. Med. 124, 921-951, 1966 
25. Palú, G., R. Powles, P. Selby, B.M. Summersgill and P. Alexander. Patterns of maturation in short-term culture of human acute myeloid leukemic cells. Br. J. Cancer 40, 719-730, 1979

26. Rabinovitch, M. Adhesion of modified erythrocytes to peripheral macrophages. Fed. Proc. 24, 428, 1965

27. Rabinovitch, M. The dissociation of the attachment and ingestion phases of phagocytosis by macrophages. Exp. Cell Res. 46, 19-28, 1967

28. Ramsay, N.K.C., D.M. Brown, M.E. Nesbit, P.F. Coccia, W. Krivit and S. Krutzik. Autonomous production of parathyroid hormone by lymphoblastic leukemia cells in culture. $J$. Pediatri. 94, 623-625, 1979

29. Roels, F., E. Wisse, B. DePrest and J. van Der Meulen. Cytochemical discrimination between catalases and peroxidases using diaminobenzidine. Histochemistry 41, 281-312, 1975

30. Shibata, A. and H. SakFKi. Phosphatase staining. Jap. J. Clin. Pathol. 34, 33-49, 1978

31. Takahashi, M., N. Takagi, Y. Yagi, G.E. Moore and D. Pressman. Immunoglobulin production in cloned subline of a human lymphocytic cell line. J. Immunol. 402, 1388-1393, 1969

32. Ueki, A., Y. Itaguchi, F. Нуодон and T. Kimoto. The receptor sites for complement $\left(\mathrm{C}_{3}\right)$ on human diploid fibroblasts. Virchows Arch. [Cell Pathol.] 18, 101-107, 1975

33. Willcox, M.B., D.W. GoldE and M.J. Cline. Cytochemical reactions of human hematopoietic cells in liquid culture. J. Histochem. Cytochem. 24, 979-983, 1976

34. ZaKhireh, B. and R.K. Root. Development of oxidase activity by human bone marrow granulocytes. Blood 98, 429-439, 1979 